\title{
Gene Expression and Survival of Acute Lymphoblastic Leukemia Cells After Allogeneic Transplant
}

\author{
DOMINIC SCHENONE, JEFFREY R. ANDOLINA, BROOKS RADEMACHER, THOMAS J. FOUNTAINE, \\ ELENA EDWARDS, LETI NUNEZ, MICHELLE QIU, SONAKSHI SHARMA and CRAIG A. MULLEN
}

Division of Pediatric Hematology/Oncology, University of Rochester, Rochester, NY, U.S.A.

\begin{abstract}
Background/Aim: This study explored the mechanisms of the allogeneic graft versus leukemia effect in acute lymphoblastic leukemia (ALL) cells by examining whether they change gene expression in the post-transplant environment containing cytokines and the immunosuppressant cyclosporine, and if such changes affect ALL cell survival. Materials and Methods: RNASeq was used to assess leukemia global gene expression and flow cytometry to measure ALL survival in the presence of $T$ cells, NK cells, cytokines, and cyclosporine. Results: A total of 4,805 genes were differentially expressed. Gene set enrichment analysis demonstrated up-regulation of biological processes related to cytokine responses, control of viral infection, and regulation of leukocyte function including proliferation. Down-regulated genes were related to mesenchymal tissue morphogenesis. ALL cells exposed to cytokines and cyclosporine retained susceptibility to T and NK cell killing, and also exhibited increased cell death without exposure to killer cells. Conclusion: A significant portion of the graft versus leukemia effect may be mediated by cytokines and cyclosporine.
\end{abstract}

Allogeneic hematopoietic stem cell transplant (HSCT) is often performed for high risk or relapsed ALL. Transplant is a multifaceted process involving drugs and/or radiation in the preparative regimen, cellular mediators of graft versus host reactions, and post-transplant cytokines (1-5). Cure of leukemia involves not only the direct antileukemic effect of preparative regimen drugs and radiation, but also, to varying

This article is freely accessible online.

Correspondence to: Craig A. Mullen, M.D., Ph.D., Pediatric Hematology/Oncology, University of Rochester, Box 777, 601 Elmwood Avenue, Rochester, New York, 14642, U.S.A. Tel: +1 5852735372, e-mail: craig_mullen@urmc.rochester.edu

Key Words: Acute lymphoblastic leukemia, graft versus leukemia, allogeneic bone marrow transplantation. degrees, the allogeneic graft versus host response. This effect is often called a graft versus leukemia effect, although the specificity of the effect for leukemia is hard to prove $(6,7)$. The antileukemia allogeneic effect is generally considered to be greater for myeloid leukemias compared to lymphoid leukemias. The reasons for this are not fully understood.

The post-transplant environment provides two unique features for residual ALL cells (8). The first is the presence of multiple cytokines produced by the allogeneic reaction. The second is the presence of immunosuppressive drugs, such as cyclosporine, which are administered to prevent graft versus host disease (GVHD).

One important question is whether the leukemia cells are passive in this post-transplant environment or whether they change in response to the post-transplant environment. If they do change, do the changes impact the leukemia cell's capacity to survive the immunologically hostile environment or do the changes contribute to the "graft versus leukemia" effect? The aim of this project was to address this question in an in vitro model of human ALL.

Many studies have measured a variety of cytokines in serum following allogeneic transplantation (9-14). The results have been heterogeneous owing in part to study methods (e.g., assaying for specific cytokines in some studies but not others, some focusing on patients with graft versus host disease). Both type I and type II cytokines have been shown to be present. The presence of IL-6, IL-10, TNFalpha, IL-2, IL-12 and interferon-gamma (among others) has been reported. Interestingly, some studies on the levels of cytokines following umbilical cord blood transplantation (typically performed to produce much less allogeneic reactivity compared to bone marrow or peripheral blood stem cell grafts) have rarely shown significant amounts of interferon-gamma, TNF-alpha, GMCSF or IL-6 (15-17).

Drugs such as cyclosporine are routinely started immediately prior to the infusion of allogeneic donor cells to inhibit the development of GVHD. Cyclosporine (and another calcineurin inhibitor, tacrolimus) has been intensely studied in the bone marrow transplant (BMT) literature, but 
Table I. Characteristics of acute lymphoblastic leukemia cells used in these studies.

\begin{tabular}{lccc}
\hline Name & Tissue & Age & Disease phase \\
\hline ALL A & Blood & Adult & Diagnosis \\
ALL B & Blood & Adult & Diagnosis \\
ALL C & Blood & Pediatric & Diagnosis \\
ALL E & Blood & Adult & Relapse \\
ALL F & Blood & Adult & Diagnosis \\
ALL G & Marrow & Pediatric & Relapse \\
\hline
\end{tabular}

nearly always from the perspective of modulation of GHVD, rather than direct anti-leukemia cell effects. There is a very limited literature on the direct effect of these drugs on ALL (18-20). There have been reports that calcineurin inhibitors can in some cases enhance leukemia cell apoptosis, especially in $\mathrm{T}$ cell acute lymphoblastic leukemia $(21,22)$.

We had previously studied changes in ALL cell gene expression in a murine model of allogeneic bone marrow transplantation (23). We discovered that leukemia cells in the allogeneic environment over-expressed genes related to immune processes, antigen presentation, ubiquitination and GTPase function. We also discovered that interferon-gamma appeared to be the dominant in vivo driver of these changes. Then we became interested in determining whether human acute lymphoblastic leukemia cells exhibit similar changes in gene expression in the post-allogeneic transplant immune environment. We developed an in vitro model in which human ALL cells were exposed to cytokines and the immunosuppressive drug, cyclosporine. Global gene expression was assessed by RNASeq. We also assessed the impact on leukemia cell survival as well as leukemia cell sensitivity to cytolytic NK and T cells.

\section{Materials and Methods}

Leukemia cells. Deidentified primary B lineage ALL cells from adult and pediatric patients were obtained from bone marrow or peripheral blood leukapheresis samples at the time of initial diagnosis or relapse (Table I). The samples were used under the auspices of an IRB approved protocol. The IRB deemed that individual patient consent was not needed since no personal identifying information was involved and the materials were from residual lab samples that would otherwise have been discarded. All samples were from patients who met the National Cancer Institute criteria for high risk ALL. Limited clinical, genetic and phenotypic data were available because of the deidentification process. Specimens were expanded a single time as patient derived xenografts in NOD-SCID mice. First-generation xenograft samples were used; i.e., leukemias were not serially passaged in mice. At 812 weeks of age, mice received 250 cGy total body irradiation. Mice were injected iv with $5 \times 10^{6}$ leukemia cells $4 \mathrm{~h}$ later. The spleen and bone marrow were harvested after 8-12 weeks. To
Table II. Human biological pathways related to murine genes upregulated in murine leukemia after allogeneic bone marrow transplant. The pathways are Gene Ontogeny biological pathways that were statistically significant at an adjusted p-value of $<0.05$.

\begin{tabular}{lc}
\hline Human biological pathway & Adjusted $p$-Value \\
\hline Response to interferon-gamma & $p<0.0000001$ \\
Cellular response to interferon-gamma & $p<0.0000001$ \\
Interferon-gamma-mediated signaling pathway & $p<0.0000001$ \\
Type I interferon signaling pathway & $p<0.0000001$ \\
Cellular response to type I interferon & $p<0.0000001$ \\
Response to type I interferon & $p<0.0000001$ \\
Response to virus & $p=0.00002$ \\
Negative regulation of viral genome replication & $p=0.0003$ \\
Defense response to virus & $p=0.0003$ \\
Regulation of viral genome replication & $p=0.0031$ \\
Viral genome replication & $p=0.011$ \\
Negative regulation of natural killer & $p=0.022$ \\
cell mediated cytotoxicity & \\
Negative regulation of viral process & $p=0.029$ \\
Dendritic cell differentiation & $p=0.048$ \\
\hline
\end{tabular}

confirm engraftment of leukemic cells, the cells were examined by flow cytometry with human CD19 and CD45 antibodies. All specimens were human CD45 positive, and human CD19 positive both before and after expansion in immunodeficient mice. We compared ALL cells before and after xenograft expansion and found no differences in flow phenotype, morphology, stromal dependence and in vitro growth potential. Table I contains information about individual samples.

Isolation of normal B cells. Peripheral blood mononuclear cells were isolated by Ficoll separation from healthy donor blood. B cells were isolated from the peripheral blood mononuclear cells (PBMCs) using CD19 microbeads (Miltenyi Biotec, Auburn, CA, USA).

Cytokine measurements. Bidirectional mixed lymphocyte reactions were established from healthy donors. Equal numbers of Ficoll purified peripheral blood mononuclear cells were placed at a total cell concentration of $2 \times 10^{6}$ cells $/ \mathrm{ml}$ in $10 \mathrm{ml} \mathrm{Aim} \mathrm{V} \mathrm{medium.} \mathrm{Control}$ cultures had cells from one donor at a concentration of $2 \times 10^{6}$ cells $/ \mathrm{ml}$. Culture supernatants were collected after 6 days. Concentrations of IFN- $\gamma$, IL-12, IL-6, TNF- $\alpha$, IL-2, GM-CSF, IL-4, IL-10, IL-17, and TGF- $\beta$ were quantified using a customized Milliplex MAP Human Cytokine/Chemokine Panel (Millipore, Schwalbach, Germany). Assays were performed according to the manufacturer's instructions and standards. Samples were quantified using median fluorescent intensity data quantified on a Luminex 100.

In vitro culture of primary acute lymphoblastic leukemia cells. Approximately $0.8 \times 10^{6}$ human bone marrow derived stromal cells immortalized with a human telomerase gene (24) were plated in $25 \mathrm{~cm}^{2}$ tissue culture flasks. One day later $5 \times 10^{6}$ first generation human xenograft ALL cells were thawed and added to the flasks and cultured in AIM V medium. Cytokines and cyclosporine were added to experimental cultures while control cultures had only AIM V. Cytokines were used at the following final concentrations: IFN- $\gamma, 5,000 \mathrm{pg} / \mathrm{ml}$; 


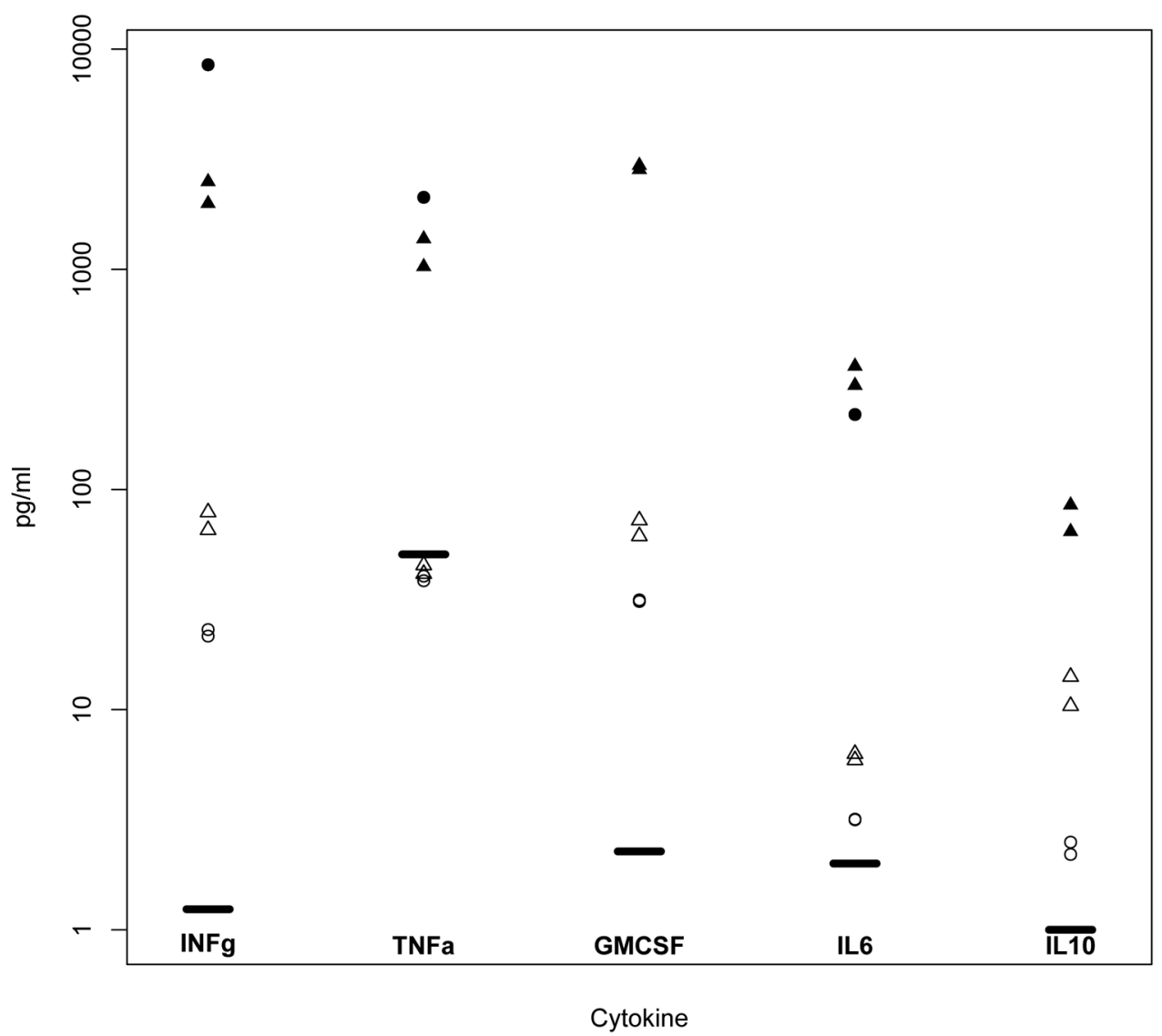

Figure 1. Concentrations of interferon-gamma, TNF-alpha, GMCSF, IL6, and IL10 in allogeneic mixed lymphocyte cultures. The black horizontal lines are background cytokine levels in lymphocyte cultures that did not receive allogeneic cell stimulation while the symbols represent individual mixed lymphocyte cultures. When a symbol appears more than once in a cytokine column it indicates a duplicate well.

TNF- $\alpha, 2,000$ pg/ml; GM-CSF, 3,000 pg/ml; IL-6, 300 pg/ml; and IL$10,50 \mathrm{pg} / \mathrm{ml}$. Cyclosporine final concentration was $200 \mathrm{ng} / \mathrm{ml}$. After $48 \mathrm{~h}$ of culture the leukemia cells were removed from the flasks and purified by flow cytometric sorting using human CD19 positive selection and negative selection using 7-aminoactinomycin D to exclude non-viable leukemia cells. For RNASeq studies leukemias A, B, E, F and G were used (Table I).

RNASeq. RNA was prepared using Qiagen RNEasy kits (Qiagen Sciences, Germantown, MD, USA). Residual genomic DNA was removed by DNAse treatment and a cDNA library was prepared. Sequencing was performed in the University of Rochester Genomics Core Facility (Rochester, NY, USA). Sequencing was performed using Illumina HiSeq 2500 Sequencer.

Cross Species Gene Set Analysis (XGSA). Experimental microarray data from mouse xenografts was processed through the Gene ID conversion utility in DAVID (25) to identify murine genes. The R based software Cross Species Gene Set Analysis (XGSA) $(26,27)$ was used to map murine genes to human Gene Ontogeny Biological Process pathways (28-30) and to compare lists of differentially expressed murine and human genes. The Benjamini-Hochberg procedure was used to correct the $p$-value in the setting of multiple comparison testing.

Gene Set Enrichment Analysis (GSEA). RNA-Seq fastq files were cleaned with FastQC (31). The raw reads were mapped using STAR $(32,33)$. Sam files were converted to and sorted into bam files with samtools $(34,35)$. Bam files were counted using HTSeq-count (36, 37). Count files were then read into DESeq2 $(38,39)$ and differential expression analysis was performed. Rank files containing a ranking metric were generated from the DESeq2 output. Gene set enrichment analysis was performed using the GSEA program $(40,41)$. Analysis was performed to determine the enrichment of gene sets in the presence of cytokines across several different B cell and leukemia cells. Several of the human datasets were compared to the mouse data from XGSA.

NK cell mediated cytotoxicity. Peripheral blood mononuclear cells were purified by standard Ficoll separation procedures. NK cells were isolated from PBMCs using CD56 magnetic microbeads following manufacturer's guidelines (Miltenyi Biotec). NK cells were incubated overnight in RPMI with $10 \%$ fetal calf serum (FCS) supplemented with human IL-2 at a final concentration of 200 
Enrichment Score of B cells

\begin{tabular}{|lccc|}
\hline GO Pathway & Cyto & Cyto \& CSA & CSA \\
\hline CELLULAR_RESPONSE_TO_INTERFERON_GAMMA & 0.87 & 0.90 & 0.00 \\
\hline DEFENSE_RESPONSE_TO_VIRUS & 0.84 & 0.85 & 0.31 \\
\hline DENDRITIC_CELL_DIFFERENTIATION & 0.43 & 0.59 & 0.00 \\
\hline INTERFERON_GAMMA_MEDIATED_SIGNALING_PATHWAY & 0.88 & 0.91 & 0.00 \\
\hline NEGATIVE_REGULATION_OF_VIRAL_GENOME_REPLICATION & 0.67 & 0.82 & 0.00 \\
\hline NEGATIVE_REGULATION_OF_VIRAL_PROCESS & 0.75 & 0.83 & 0.00 \\
\hline REGULATION_OF_TYPE_IINF_MEDIATED_SIGNALING_PATHWAY & 0.83 & 0.89 & 0.00 \\
\hline REGULATION_OF_VIRAL_GENOME_REPLICATION & 0.72 & 0.78 & 0.00 \\
\hline RESPONSE_TO_INTERFERON_GAMMA & 0.87 & 0.89 & 0.00 \\
\hline GO_RESPONSE_TO_TYPE_I_INTERFERON & 0.88 & 0.92 & 0.00 \\
\hline RESPONSE_TO_VIRUS & 0.78 & 0.82 & 0.00 \\
\hline VIRAL_GENOME_REPLICATION & 0.38 & 0.51 & 0.00 \\
\hline
\end{tabular}

Figure 2. Comparison of enrichment scores of biological function pathways in B cells induced by the cytokine mixture and/or cyclosporine. "Cyto" refers to cytokine mixture added to cell culture, "CSA" refers to cyclosporine, "Cyto \& CSA" is cytokine mixture and cyclosporine. Comparisons were made to control cultures to which neither cytokines nor cyclosporine were added.

$\mathrm{IU} / \mathrm{ml}$. Prior to being mixed with the NK cells, leukemia cells were either untreated or preincubated for $48 \mathrm{~h}$ with cytokines and cyclosporine. To assess NK cytotoxicity against leukemia cells, $2 \times 10^{4}$ ALL cells and $6 \times 10^{4} \mathrm{NK}$ cells were added to microwells containing stromal cells in a total volume of $200 \mu \mathrm{l}$ of RPMI medium with $10 \%$ FCS. Live leukemia cells were counted using flow cytometric techniques 5 days later.

Activated T cell mediated cytotoxicity. PBMCs were purified by standard Ficoll separation procedures. $\mathrm{T}$ cells were isolated from PBMCs using CD3 magnetic microbeads following manufacturer's guidelines (Miltenyi Biotec). $\mathrm{T}$ cells were then activated by incubation for $24 \mathrm{~h}$ with CD3/CD28 Dynabeads (Thermo Fisher Scientific, Waltham, MA, USA). Then, $3 \times 10^{4}$ leukemia cells and $1.5 \times 10^{4}$ activated $\mathrm{T}$ cells were added to microwells containing stromal cells in a total volume of 200 microliters of RPMI medium with $10 \%$ FCS. Live leukemia cells were counted using flow cytometric techniques 5 days later.

\section{Results}

Mapping of murine leukemia gene expression changes to human pathways. As an initial step in our studies, we performed a reanalysis of previously generated data from our in vivo murine leukemia allogeneic transplant experiments (23). Our earlier study of murine acute lymphoblastic leukemia in the in vivo post-transplant environment had used Affymetrix Mouse 430.2 microarrays to assess gene expression. We identified 455 differentially expressed murine genes in ALL cells recovered from mice that had undergone allogeneic transplant. These murine genes were mapped to human Gene Ontology Biological Pathways using the R- based Cross Species Gene Set Analysis software. Table II lists the human pathways associated with these differentially expressed genes. The dominant theme was responses to type 1 interferons and regulation of viral replication.

Rationale for cytokine concentrations. To in vitro simulate the cytokine and immunosuppressant drug milieu of ALL cells in the post-allogeneic transplant environment, cytokine and cyclosporine concentrations used in vitro were determined. We conducted a literature survey to collect such information (9-13). We also experimentally measured cytokine concentrations produced in vitro by human mixed lymphocyte cultures (Figure 1). We did not detect significant concentrations of the following cytokines: IL-12, IL-4, IL-2, IL-17 or TGF-beta. Based on these results we chose to use the following cytokines in the ALL cultures: IFN- $\gamma(5,000$ $\mathrm{pg} / \mathrm{ml})$, TNF- $\alpha(2,000 \mathrm{pg} / \mathrm{ml}), \mathrm{GM}-\mathrm{CSF}(3,000 \mathrm{pg} / \mathrm{ml}), \mathrm{IL}-6$ $(300 \mathrm{pg} / \mathrm{ml})$, and IL-10 (50 pg/ml).

Cyclosporine does not markedly alter gene expression changes induced by cytokines in nonmalignant B cells. In our earlier report mice that underwent allogeneic transplant were not treated with cyclosporine (23). We conducted experiments in vitro to determine whether cyclosporine at therapeutic concentrations used in humans would have a major impact on biological pathways in leukemia cells exposed to transplant associated cytokines. Normal human peripheral B cells were exposed to the cytokine mixture and/or cyclosporine in vitro for $48 \mathrm{~h}$ and RNASeq and pathway analysis studies of differentially expressed genes 
were performed. Figure 2 is a heatmap that presents pathway enrichment scores of differentially expressed genes by $\mathrm{B}$ cells. The expression pattern of cells treated with cytokines plus cyclosporine was very similar to those of B cells treated with cytokines alone. The comparison is to untreated B cells. Similar results were observed with continuously growing ALL cell lines treated with cytokines and/or cyclosporine (data not shown). Based on this information we examined gene expression in primary human ALL xenografts treated with or without the combination of cytokines and cyclosporine. Our rationale was that this would be analogous to the in vivo human experience.

Gene expression changes in human ALL cells. Five unique human ALLs were cultured on stromal cells for $48 \mathrm{~h}$ in the presence or absence of cytokines plus cyclosporine. RNASeq using paired samples and uniquely mapping reads was used to assess gene expression. A total of 4,805 genes were differentially expressed at an adjusted significance p-value less than 0.05. 2,504 genes were over-expressed and 2,301 genes were under-expressed in the cytokine/cyclosporine treated samples compared to the control samples. Figure 3 is a heat map of the 50 most differentially expressed genes.

We performed gene set enrichment analysis and found 51 Gene Ontogeny pathways up-regulated and 28 pathways down-regulated (both using a false discovery rate of less than 0.05). Table III presents the up-regulated pathways. Common themes among the up-regulated genes included biologic processes related to cytokine responses, control of viral infection and regulation of leukocyte function including proliferation. Table IV presents the down-regulated pathways. The dominant theme among the down-regulated genes was regulation of mesenchymal tissue morphogenesis.

We also performed RNASeq and gene set enrichment analysis on 4 continuously growing, nonstromal cell dependent human cell lines derived from pediatric ALL patients (One B ALL line, 2 T ALL lines, and 1 EBV immortalized B cell line from a patient with B ALL). We observed results very similar to the leukemia xenografts (Data not shown).

Effect of cytokines and cyclosporine on leukemia cell survival. The gene expression data showed that pathways related to immune response to infection, especially viral infection, were activated in the leukemia cells. While $\mathrm{T}$ cell adaptive immune responses often involve direct cell mediated cytolysis of infected cells, another significant component of the defense response to viral infection involves cytokine mediated impairment of survival of virus infected cells (42). We asked whether the cytokine/cyclosporine environment had such an effect on leukemia cell survival. We incubated human leukemia cells on stromal cells in the presence of the cytokines and/or cyclosporine. We measured leukemia survival 4 days later. Figure 4 demonstrates that in

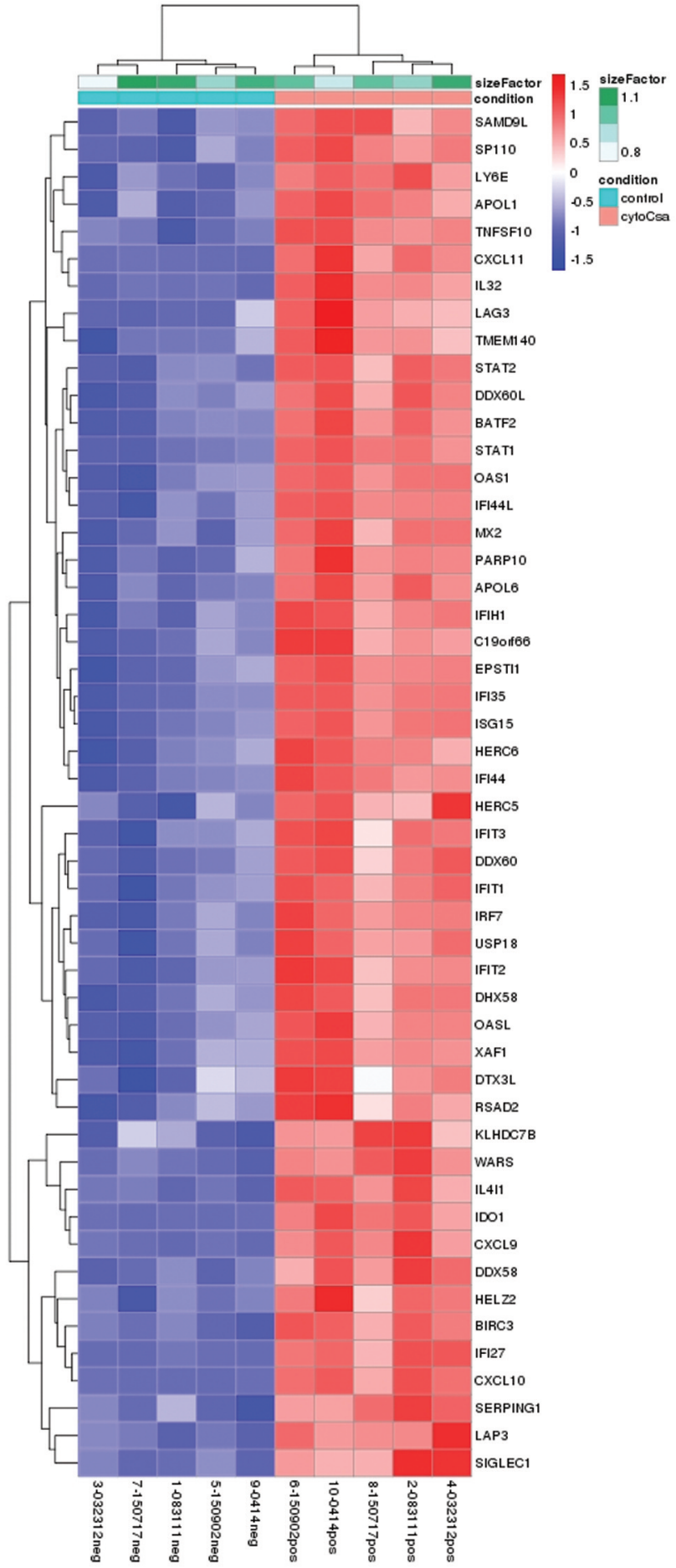

Figure 3. Expression data of the 50 most significantly differentially expressed genes. The data are regularized log transformation of the normalized count data. Samples and genes are hierarchically clustered. Gene names are on the right side and sample names at the bottom. Key for sample names. The first digit is the sample number. "pos" means cells were exposed to cytokines and cyclosporine while "neg" means they were not. "150902" is ALL F, "0414" is ALL G, "150717" is ALL E, "083111" is ALL A, and "032312" is ALL B. 
Table III. Pathways among genes over-expressed in leukemia cells exposed to cytokines and cyclosporine compared to control leukemia cells. The pathways are Gene Ontogeny biological pathways that were statistically significant at an adjusted p-value of $<0.05$.

\begin{tabular}{|c|c|c|}
\hline PATHWAY & NES & FDR \\
\hline GO_RESPONSE_TO_VIRUS & 2.08 & 0.000 \\
\hline GO_DEFENSE_RESPONSE_TO_VIRUS & 2.08 & 0.000 \\
\hline GO_CYTOKINE_MEDIATED_SIGNALING_PATHWAY & 2.06 & 0.000 \\
\hline GO_IMMUNE_EFFECTOR_PROCESS & 2.05 & 0.000 \\
\hline GO_DEFENSE_RESPONSE_TO_OTHER_ORGANISM & 2.05 & 0.000 \\
\hline GO_RESPONSE_TO_INTERFERON_GAMMA & 2.04 & 0.000 \\
\hline GO_REGULATION_OF_INNATE_IMMUNE_RESPONSE & 2.00 & 0.000 \\
\hline GO_CELLULAR_RESPONSE_TO_INTERFERON_GAMMA & 1.98 & 0.000 \\
\hline GO_NEGATIVE_REGULATION_OF_VIRAL_PROCESS & 1.97 & 0.000 \\
\hline GO_INTERFERON_GAMMA_MEDIATED_SIGNALING_PATHWAY & 1.95 & 0.000 \\
\hline GO_NEGATIVE_REGULATION_OF_MULTI_ORGANISM_PROCESS & 1.94 & 0.000 \\
\hline GO_RESPONSE_TO_TYPE_I_INTERFERON & 1.93 & 0.000 \\
\hline GO_ACTIVATION_OF_INNATE_IMMUNE_RESPONSE & 1.93 & 0.000 \\
\hline GO_REGULATION_OF_VIRAL_GENOME_REPLICATION & 1.92 & 0.000 \\
\hline GO_REGULATION_OF_SYMBIOSIS_ENCOMPASSING_MUTUALISM_THROUGH_PARASITISM & 1.91 & 0.000 \\
\hline GO_REGULATION_OF_TYPE_I_INTERFERON_PRODŪCTION & 1.91 & 0.000 \\
\hline GO_POSITIVE_REGULATION_OF_DEFENSE_RESPONSE & 1.91 & 0.000 \\
\hline GO_POSITIVE_REGULATION_OF_INNATE_IMMUNE_RESPONSE & 1.90 & 0.000 \\
\hline GO_NEGATIVE_REGULATION_OF_VIRAL_GENOME_REPLICATION & 1.89 & 0.001 \\
\hline GO_REGULATION_OF_MULTI_ORGANISM_PROCESS & 1.89 & 0.001 \\
\hline GO_POSITIVE_REGULATION_OF_CYTOKINE_PRODUCTION & 1.89 & 0.001 \\
\hline GO_INFLAMMATORY_RESPONSE & 1.87 & 0.002 \\
\hline GO_PATTERN_RECOGNITION_RECEPTOR_SIGNALING_PATHWAY & 1.87 & 0.002 \\
\hline GO_ACTIVATION_OF_IMMUNE_RESPONSE & 1.86 & 0.003 \\
\hline GO_REGULATION_OF_IMMUNE_EFFECTOR_PROCESS & 1.86 & 0.003 \\
\hline GO_NEGATIVE_REGULATION_OF_TYPE_I_INTERFERON_PRODUCTION & 1.84 & 0.005 \\
\hline GO_REGULATION_OF_LEUKOCYTE_MEDIATED_IMMUNITY & 1.84 & 0.005 \\
\hline GO_POSITIVE_REGULATION_OF_IMMUNE_EFFECTOR_PROCESS & 1.84 & 0.006 \\
\hline GO_TUMOR_NECROSIS_FACTOR_MEDIATED_SIGNALING_PATHWAY & 1.82 & 0.011 \\
\hline GO_NEGATIVE_REGULATION_OF_CYTOKINE_PRODUCTION & 1.82 & 0.011 \\
\hline GO_POSITIVE_REGULATION_OF_TYPE_I_INTERFERON_PRODUCTION & 1.82 & 0.012 \\
\hline GO_TOLL_LIKE_RECEPTOR_SIGNALING_PATHWAY & 1.82 & 0.013 \\
\hline GO_REGULATION_OF_LEUKOCYTE_MEDIATED_CYTOTOXICITY & 1.81 & 0.016 \\
\hline GO_RESPONSE_TO_TUMOR_NECROSIS_FACTOR & 1.80 & 0.018 \\
\hline GO_RESPONSE_TO_MOLECULE_OF_BACTERIAL_ORIGIN & 1.80 & 0.018 \\
\hline GO_REGULATION_OF_LYMPHOCYTE_MEDIATED_IMMUNITY & 1.80 & 0.021 \\
\hline GO_REGULATION_OF_I_KAPPAB_KINASE_NF_KAPPAB_SIGNALING & 1.80 & 0.022 \\
\hline GO_REGULATION_OF_ADAPTIVE_IMMUNE_RESPONSE & 1.80 & 0.021 \\
\hline GO_NEGATIVE_REGULATION_OF_HOMOTYPIC_CELL_CELL_ADHESION & 1.79 & 0.022 \\
\hline GO_LYMPHOCYTE_CHEMOTAXIS & 1.79 & 0.022 \\
\hline GO_REGULATION_OF_CELL_KILLING & 1.79 & 0.023 \\
\hline GO_RESPONSE_TO_BACTERIUM & 1.79 & 0.024 \\
\hline GO_NIK_NF_KĀPPĀB_SIGNALING & 1.78 & 0.027 \\
\hline GO_NEGATIVE_REGULATION_OF_LEUKOCYTE_PROLIFERATION & 1.78 & 0.029 \\
\hline GO_INNATE_IMMUNE_RESPONSE_ACTIVATING_CELL_SURFACE_RECEPTOR_SIGNALING_PATHWAY & 1.77 & 0.036 \\
\hline GO_LYMPHOCYTE_MIGRATION & 1.77 & 0.041 \\
\hline GO_REGULATION_OF_LEUKOCYTE_PROLIFERATION & 1.76 & 0.045 \\
\hline GO_POSITIVE_REGULATION_OF_CELL_KILLING & 1.76 & 0.046 \\
\hline GO_LEUKOCYTE_CHEMOTAXIS & 1.76 & 0.045 \\
\hline GO_CHEMOKINE_MEDIATED_SIGNALING_PATHWAY & 1.76 & 0.047 \\
\hline
\end{tabular}

all 5 leukemias cell survival was significantly impaired in the presence of both cytokines and cyclosporine compared to untreated controls. We also assessed the effect of cytokines and cyclosporine alone. We observed heterogeneity of effects among the 5 leukemias. Four of the 5 exhibited sensitivity to the cytokines alone. Three of the 5 exhibited major sensitivity and 2 of the 5 modest sensitivity to cyclosporine alone. 
Table IV. Pathways among genes under-expressed in leukemia cells exposed to cytokines and cyclosporine compared to control leukemia cells. The pathways are Gene Ontogeny biological pathways that were statistically significant at an adjusted p-value of $<0.05$.

\begin{tabular}{|c|c|c|}
\hline NAME & NES & FDR \\
\hline GO_EMBRYONIC_SKELETAL_SYSTEM_DEVELOPMENT & -1.89 & 0.016 \\
\hline GO_SPECIFICATION_OF_SYMMETRY & -1.87 & 0.013 \\
\hline GO_EMBRYONIC_HEART_TUBE_DEVELOPMENT & -1.85 & 0.017 \\
\hline GO_ARTERY_MORPHOGENESIS & -1.84 & 0.014 \\
\hline GO_HEART_MORPHOGENESIS & -1.84 & 0.012 \\
\hline GO_NEURON_FATE_COMMITMENT & -1.83 & 0.012 \\
\hline GO_COLLAGEN_FIBRIL_ORGANIZATION & -1.83 & 0.010 \\
\hline GO_EPITHELIAL_TO_MESENCHYMAL_TRANSITION & -1.82 & 0.011 \\
\hline GO_ARTERY_DEVELOPMENT & -1.82 & 0.011 \\
\hline GO_ORGAN_GROWTH & -1.82 & 0.010 \\
\hline GO_REPLACEMENT_OSSIFICATION & -1.82 & 0.010 \\
\hline GO_NEGATIVE_REGULATION_OF_BMP_SIGNALING_PATHWAY & -1.81 & 0.010 \\
\hline GO_POLYSACCHARIDE_CATABOLIC_PROCESS & -1.80 & 0.010 \\
\hline GO_REGULATION_OF_MORPHOGENESIS_OF_A_BRANCHING_STRUCTURE & -1.80 & 0.012 \\
\hline GO_EMBRYONIC_DIGIT_MORPHOGENESIS & -1.79 & 0.015 \\
\hline GO_MESENCHYME_MORPHOGENESIS & -1.79 & 0.014 \\
\hline GO_EMBRYONIC_HEART_TUBE_MORPHOGENESIS & -1.78 & 0.015 \\
\hline GO_ENDOCHONDRAL_BONE_MOTERHOGENESIS & -1.76 & 0.024 \\
\hline GO_HEART_DEVELOPMENT & -1.76 & 0.024 \\
\hline GO_AORTA_DEVELOPMENT & -1.76 & 0.023 \\
\hline GO_AORTA_MORPHOGENESIS & -1.75 & 0.026 \\
\hline GO_CELL_FATE_SPECIFICATION & -1.75 & 0.027 \\
\hline GO_OUTFLOWO_TRACT_MORPHOGENESIS & -1.75 & 0.027 \\
\hline GO_ENDOCARDIAL_CUSHION_DEVELOPMENT & -1.73 & 0.039 \\
\hline GO_DIGESTIVE_SYSTEM_DEVELOPMENT & -1.73 & 0.038 \\
\hline GO_MESONEPHROS_DEVELOPMENT & -1.72 & 0.037 \\
\hline GO_NEURON_RECOGNITION & -1.71 & 0.045 \\
\hline GO_NEPHRON_DEVELOPMENT & -1.71 & 0.044 \\
\hline
\end{tabular}

Potential effects on antileukemia cell mediated cytotoxicity. In allogeneic hematopoietic stem cell transplantation donor immune cells are present and may exert cytotoxic effects on recipient leukemia cells that survive the preparative regimen. While we showed above that the cytokine/cyclosporine environment did by itself impair leukemia cell survival, we asked the question of whether the leukemia cells that survive this effect would exhibit resistance to either NK cells or cytolytic $\mathrm{T}$ cells. To test this hypothesis, we incubated leukemia cells in the cytokine/cyclosporine mixture for 2 days, and then used the incubated leukemia cells as targets for either activated NK cells or activated T cells. Figure 5 shows that leukemia cells exposed to the cytokines and cyclosporine remained very sensitive to activated NK cells.

Similar experiments were performed with activated T cells as killer cells. Figure 6 shows that leukemia cells exposed to cytokines and cyclosporine remained sensitive to activated $\mathrm{T}$ cells.

\section{Discussion}

These studies addressed the question of whether ALL cells in the post-transplant environment exhibited changes in gene expression, and, if so, whether such changes had any impact on leukemia cell survival or altered their sensitivity to cytolytic cells. We discovered that ALL cells did exhibit major changes in gene expression. Up-regulated genes clustered in gene expression pathways related to anti-viral metabolic and immune responses, innate immunity, and lymphocyte proliferation and migration. In contrast, genes clustered in pathways related to mesenchymal tissue organogenesis were down-regulated.

Much of what is known about these pathways in general is derived from the study of normal cells. One can speculate that some of these changes may contribute to the survival of these leukemia cells which after all are malignant B lymphocytes. The overall thrust of an innate or adaptive immune response is to enhance the expansion and activity of relevant lymphocyte populations. Such adaptations might increase survival of lymphocytes in an environment with inflammatory cytokines. Alternatively, many of the changes related to antiviral immunity or interferon signaling may suppress metabolic processes in or induce apoptosis in cells, teleologically to impair the spread of viruses or intracellular pathogens by killing the cells harboring them. 
ALL A

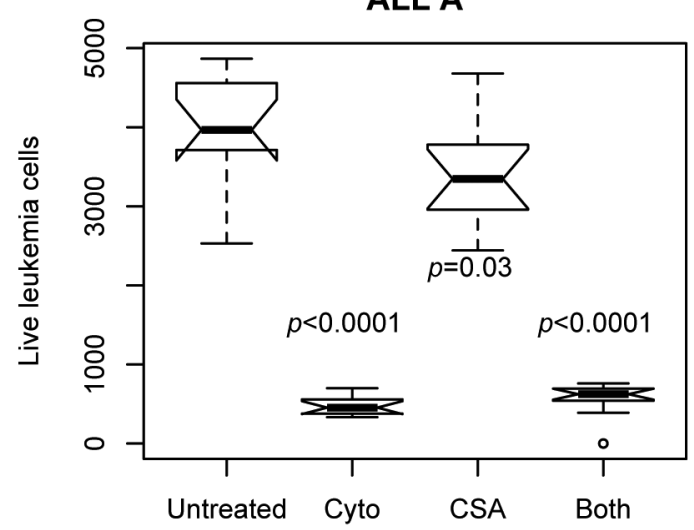

ALL E

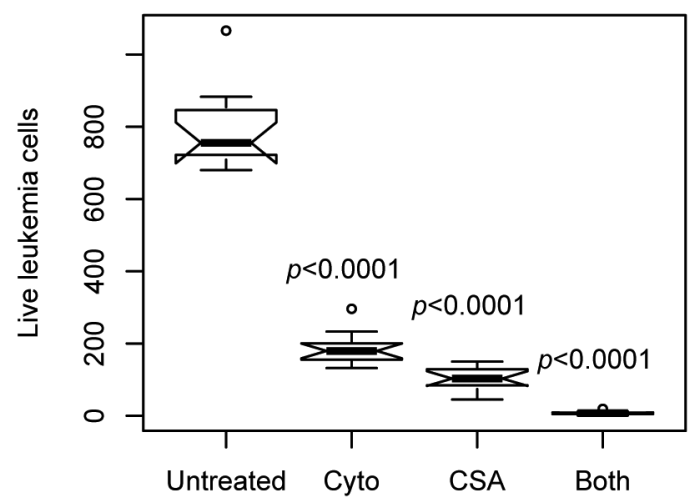

ALL G

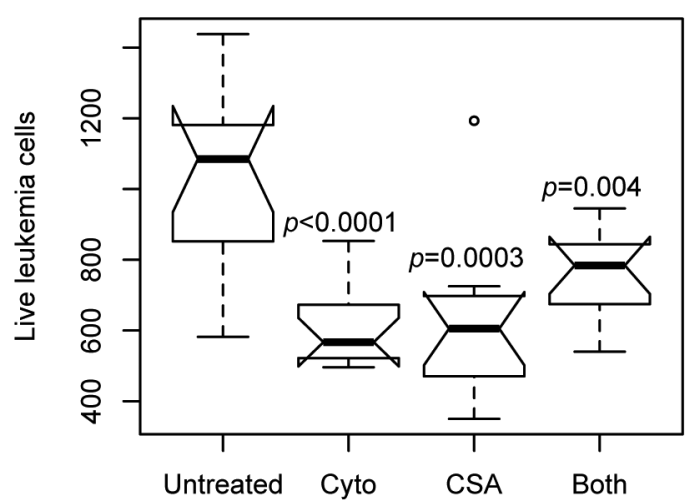

ALL B

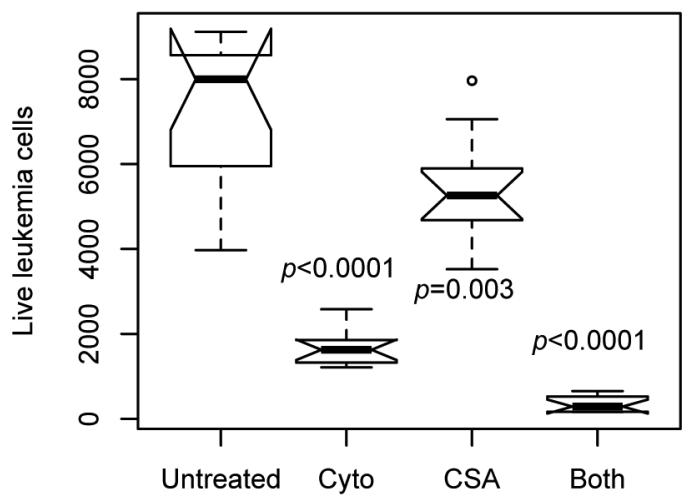

ALL F

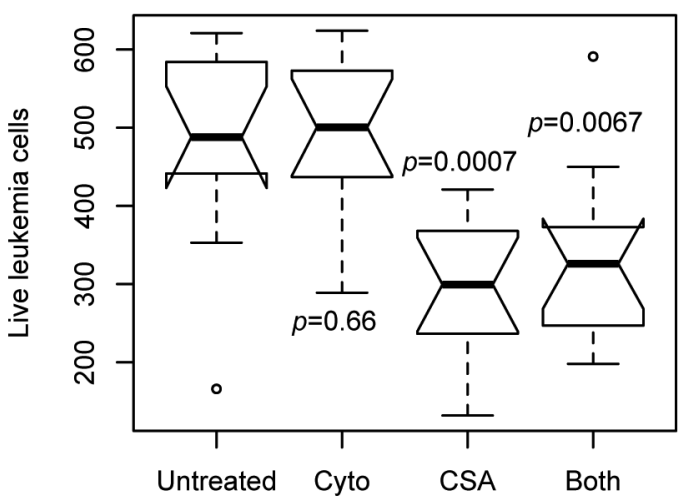

Stroma

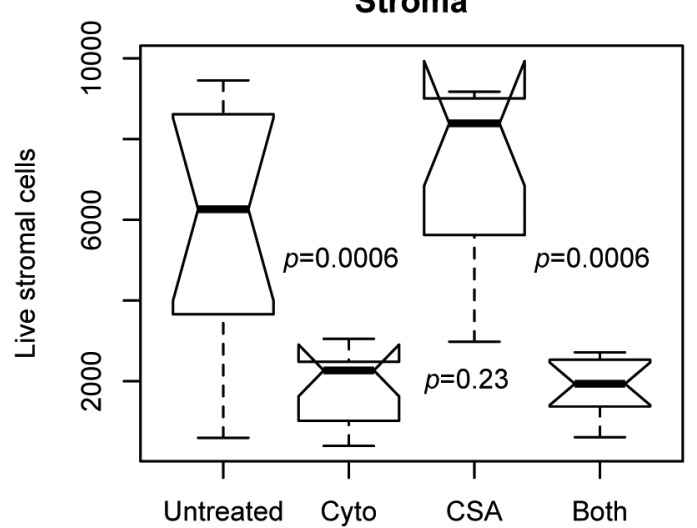

Figure 4. Survival of cells exposed to cytokines and/or cyclosporine. Box and whiskers plots provide the medians, upper and lower quartiles and range of the results. "Untreated" are control cultures, "Cyto" are cultures with the cytokines alone, "CSA" are cultures with cyclosporine alone, and "Both" are cultures with both cytokines and cyclosporine. The label above each figure is the cell type reported. The numbers above the experimental groups represent p-values relative to "untreated" cultures. There were 12 replicate cultures for each condition.

Between these possibilities our data shows that leukemia cell survival is reduced by exposure to cytokines and cyclosporine. The specific mechanism of the leukemia cell death is not established by these studies. There is a literature on the impact of inflammatory cytokines on hematopoiesis that shows interferon-gamma inhibits normal hematopoiesis (43). There is conflicting literature on the effect on malignant B cells with some reports showing impairment (44) and 
ALL A

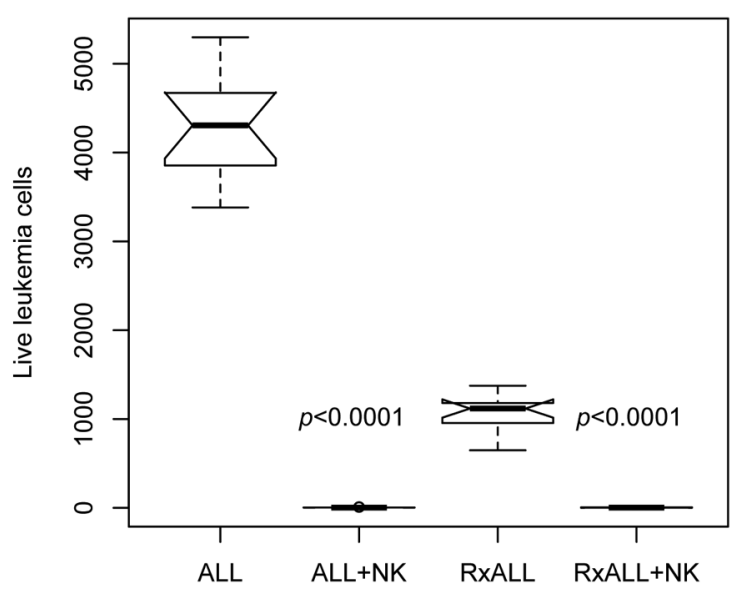

ALL F

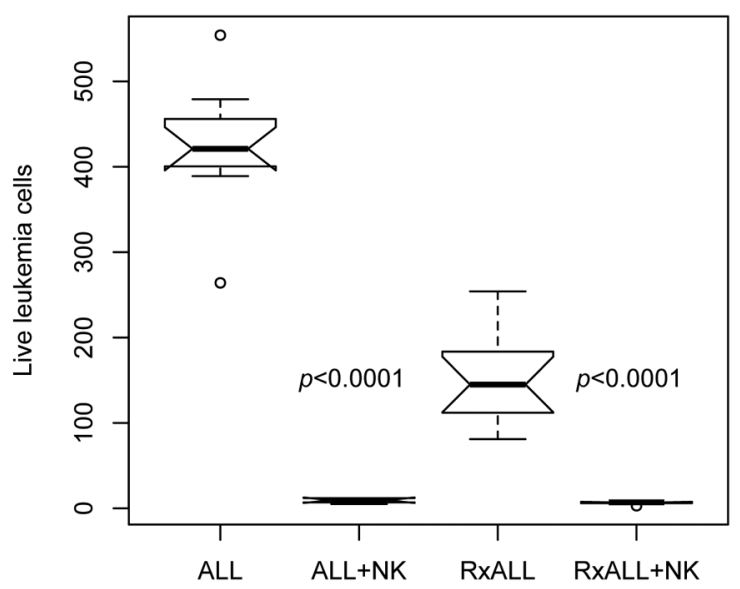

ALL B

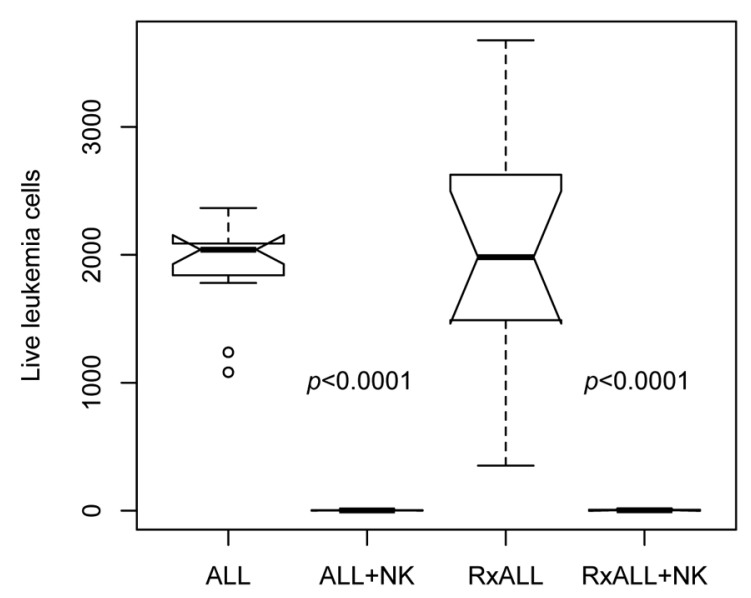

ALL G

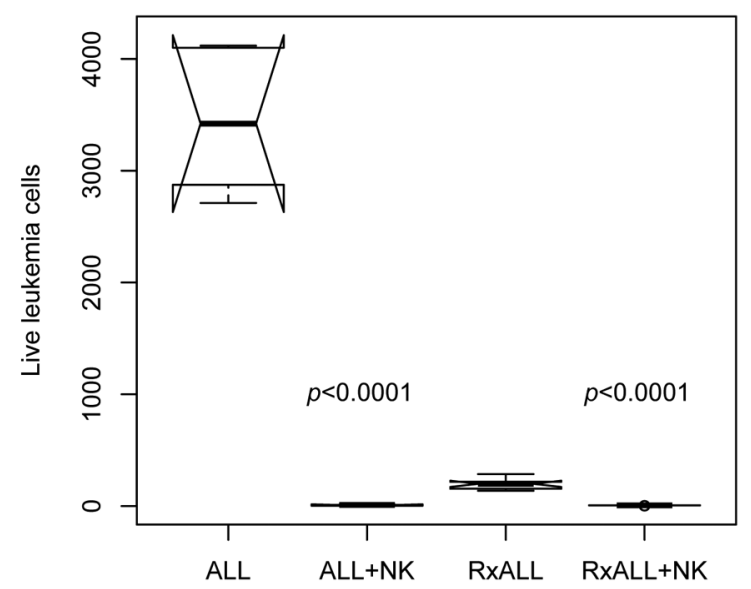

Figure 5. Leukemia cells exposed to cytokines and cyclosporine remain sensitive to natural killer cells. The label above each figure identifies the $A L L$ studied. Box and whiskers plots provide the medians, upper and lower quartiles and range of the results. "ALL" represents ALL not exposed to cytokines and cyclosporine. "ALL+NK" represents ALL not exposed to cytokines and cyclosporine but exposed to NK cells. The number above this column represents the $p$ value of the comparison of "ALL" to "ALL+NK". "RxALL" represents ALL exposed to cytokines and cyclosporine. "RxALL+NK" represents ALL exposed to cytokines and cyclosporine but exposed to NK cells. The number above this column represents the $p$ value of the comparison of "RxALL" to "RxALL+NK". There were between 4 and 12 replicates of each condition depending upon availability of cells.

others showing growth enhancement (45). Our data suggest that in the setting of allogeneic transplant the net effect is impairment of malignant $B$ cell survival with both the cytokines and cyclosporine contributing to leukemia cell death. We did observe considerable variability among different ALLs regarding the relative effects of cytokines and cyclosporine.

In the allogeneic hematopoietic stem cell literature, there is evidence that there is an allogeneic graft versus leukemia effect in acute lymphoblastic leukemia (46). It is very closely tied to graft versus host disease. A survival benefit of allogeneic reactivity on overall survival in ALL is seen only with mild GVHD. The mechanisms for the graft versus leukemia are not fully known. Much of the literature has focused on T cell and NK cell antileukemia cytolytic activity, although some studies have pointed to a role for interferon gamma (44, 47-49). In our system, we asked the question of whether the changes in ALLs induced by the cytokines and cyclosporine would change their sensitivity to allogeneic cytolytic cells. We found that cytokine/cyclosporine treated leukemia cells remained fully sensitive to the NK or T cell mediated cytolysis. 
ALL C

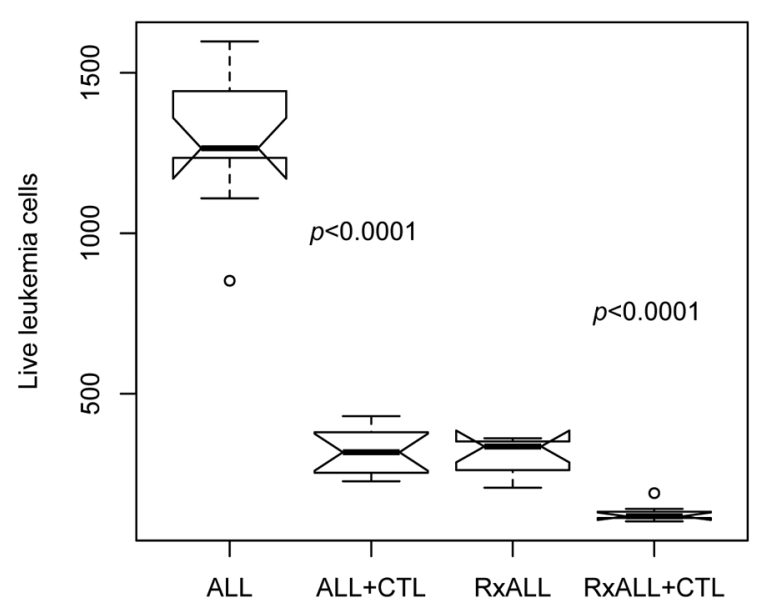

ALL F

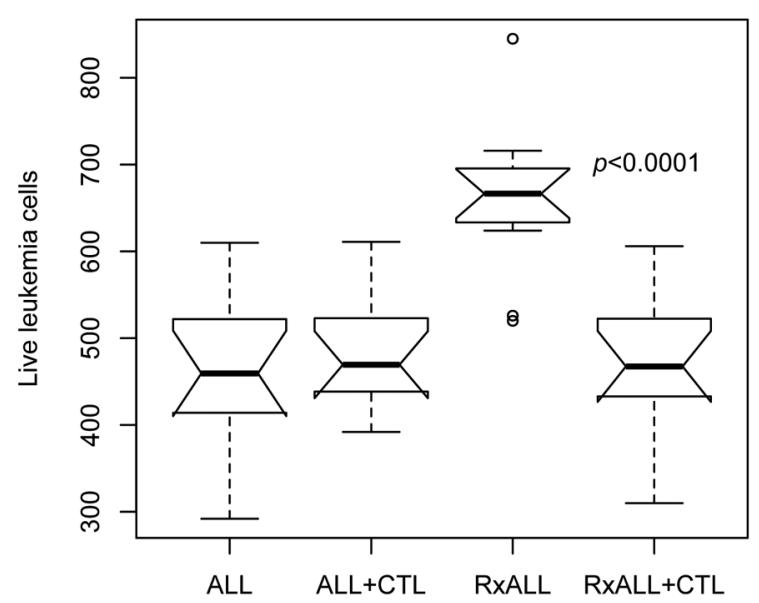

ALL E

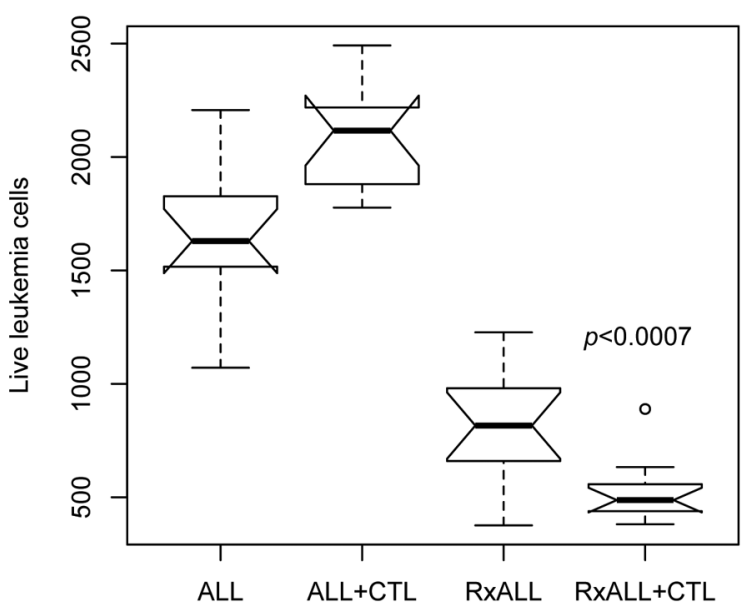

ALL G

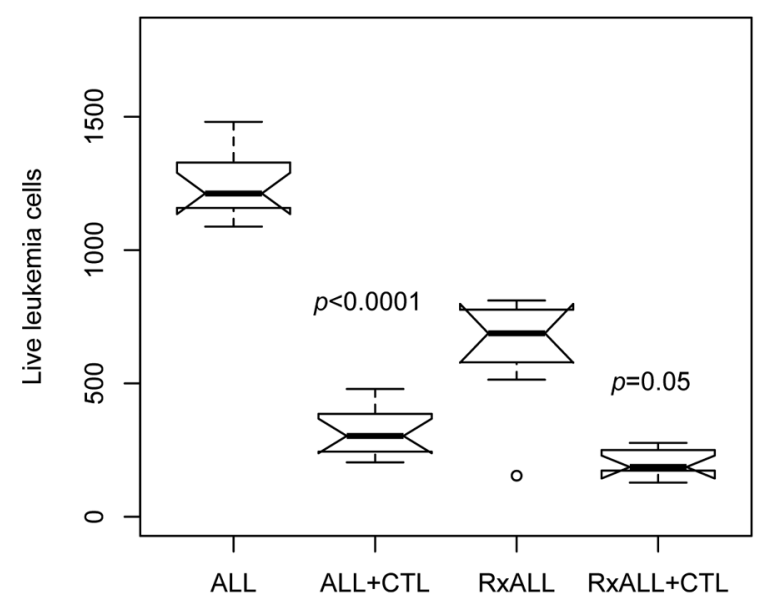

Figure 6. Leukemia cells exposed to cytokines and cyclosporine remain sensitive to activated cytolytic T cells. The label above each figure identifies the ALL studied. Box and whiskers plots provide the medians, upper and lower quartiles and range of the results; in some columns there were outliers which are identified by the small circles. "ALL" represents ALL not exposed to cytokines and cyclosporine. "ALL+CTL" represents ALL not exposed to cytokines and cyclosporine but exposed to CTL cells. The number above this column represents the $p$ value of the comparison of "ALL" to "ALL+CTL". "RxALL" represents ALL exposed to cytokines and cyclosporine. "RxALL+CTL" represents ALL exposed to cytokines and cyclosporine but exposed to CTL cells. The number above this column represents the p value of the comparison of "RxALL" to "RxALL+CTL". There were between 7 and 12 replicates of each condition depending upon availability of cells.

We observed that many gene expression pathways related to mesenchymal tissue morphogenesis (Table IV) were related to genes whose expression was depressed by exposure to cytokines and cyclosporine. We hypothesize that similar gene expression changes may be induced by the cytokines and cyclosporine in the nonmalignant mesenchymal stem cells in the marrow, conceivably affecting bone and bone microenvironment formation after transplant. There have been observations that interferon gamma can interfere with (50) bone formation.
Our study model has strengths such as use of human leukemia xenografts instead of established immortal leukemia cell lines, well defined, consistent cytokine environment and the inclusion of the very relevant immunosuppressant drug cyclosporine. However, it has also limitations. First, it is an in vitro representation of a complex in vivo process. However, we believe that the similarity of the genetic pathways we observed in our in vivo murine model (Table II) to those we observed in our in vitro human model (Table III) lends credibility to the observations we report in this work. Second, 
in the leukemia xenografts gene expression the independent effects of cytokines and cyclosporine were not assessed. Doing so would have provided a more elegant experimental design that unfortunately exceeded our resources for the expensive RNASeq studies. Nonetheless, the observation of similar biological pathways in normal B cells exposed to the cytokines with or without cyclosporine (Figure 2) suggests that most of the observed changes in gene expression were driven by the cytokines and not the cyclosporine.

\section{Conflicts of Interest}

The Authors have no conflicts of interest to report in relation to this study.

\section{Authors' Contributions}

Data generation (DS, JRA, BR, EE, LN, MQ, SS), Experimental design (CAM, DS, JRA), Data analysis (DS, JRA, TJF, CAM), Concept development and manuscript preparation (CAM). All Authors participated in the internal review of the manuscript prior to submission.

\section{Acknowledgements}

This work was funded by a research grant from Hyundai Hope On Wheels (Fountain Valley, CA, USA).

\section{References}

1 Craddock C, Hoelzer D and Komanduri KV: Current status and future clinical directions in the prevention and treatment of relapse following hematopoietic transplantation for acute myeloid and lymphoblastic leukemia. Bone Marrow Transplant 54(1): 6-16, 2019. PMID: 29855562. DOI: 10.1038/s41409-018-0203-8

2 DeFilipp Z, Advani AS, Bachanova V, Cassaday RD, Deangelo DJ, Kebriaei P, Rowe JM, Seftel MD, Stock W, Tallman MS, Fanning S, Inamoto Y, Kansagra A, Johnston L, Nagler A, Sauter CS, Savani BN, Perales MA, Carpenter PA, Larson RA and Weisdorf D: Hematopoietic cell transplantation in the treatment of adult acute lymphoblastic leukemia: Updated 2019 evidence-based review from the American Society for transplantation and cellular therapy. Biol Blood Marrow Transplant 25(11): 2113-2123, 2019. PMID: 31446198. DOI: 10.1016/j.bbmt.2019.08.014

3 Parker C, Krishnan S, Hamadeh L, Irving JAE, Kuiper RP, Révész T, Hoogerbrugge P, Hancock J, Sutton R, Moorman AV and Saha V: Outcomes of patients with childhood B-cell precursor acute lymphoblastic leukaemia with late bone marrow relapses: long-term follow-up of the ALLR3 open-label randomised trial. Lancet Haematol 6(4): e204-e216, 2019. PMID: 30826273. DOI: 10.1016/S2352-3026(19)30003-1

4 Saadeh SS and Litzow MR: Hematopoietic stem cell transplant in adults with acute lymphoblastic leukemia: the present state. Expert Rev Hematol 11(3): 195-207, 2018. PMID: 29376437. DOI: $10.1080 / 17474086.2018 .1433030$

5 Inbar T, Rowe JM and Horowitz NA: Which patients should I transplant with acute lymphoblastic leukemia? Best Pract Res
Clin Haematol 30(3): 249-260, 2017. PMID: 29050698. DOI: 10.1016/j.beha.2017.07.005

6 Kato M, Kurata M, Kanda J, Kato K, Tomizawa D, Kudo K, Yoshida N, Watanabe K, Shimada H, Inagaki J, Koh K, Goto H, Kato K, Cho Y, Yuza Y, Ogawa A, Okada K, Inoue M, Hashii Y, Teshima T, Murata M and Atsuta Y: Impact of graft-versus-host disease on relapse and survival after allogeneic stem cell transplantation for pediatric leukemia. Bone Marrow Transplant 54(1): 68-75, 2019. PMID: 29795428. DOI: 10.1038/s41409018-0221-6

7 Dickinson AM, Norden J, Li S, Hromadnikova I, Schmid C, Schmetzer H and Jochem-Kolb H: Graft-versus-leukemia effect following hematopoietic stem cell transplantation for leukemia. Front Immunol 8: 496, 2017. PMID: 28638379. DOI: 10.3389/ fimmu 2017.00496

8 Ferrara JL, Levine JE, Reddy P and Holler E: Graft-versus-host disease. Lancet 373(9674): 1550-1561, 2009. PMID: 19282026. DOI: 10.1016/S0140-6736(09)60237-3

9 Visentainer JE, Lieber SR, Persoli LB, Vigorito AC, Aranha FJ, de Brito Eid KA, Oliveira GB, Miranda EC and de Souza CA: Serum cytokine levels and acute graft-versus-host disease after HLA-identical hematopoietic stem cell transplantation. Exp Hematol 31(11): 1044-1050, 2003. PMID: 14585368. DOI: 10.1016/j.exphem.2003.08.005

10 Ferrà C, de Sanjosé S, Gallardo D, Berlanga JJ, Rueda F, Marìn $\mathrm{D}$, de la Banda E, Ancìn I, Peris J, Garcìa $J$ and Grañena A: IL6 and IL-8 levels in plasma during hematopoietic progenitor transplantation. Haematologica 83(12): 1082-1087, 1998. PMID: 9949625.

11 Min CK, Lee WY, Min DJ, Lee DG, Kim YJ, Park YH, Kim HJ, Lee S, Kim DW, Lee JW, Min WS and Kim CC: The kinetics of circulating cytokines including IL-6, TNF-alpha, IL-8 and IL-10 following allogeneic hematopoietic stem cell transplantation. Bone Marrow Transplant 28(10): 935-940, 2001. PMID: 11753547. DOI: $10.1038 /$ sj.bmt. 1703258

12 Ju XP, Xu B, Xiao ZP, Li JY, Chen L, Lu SQ and Huang ZX: Cytokine expression during acute graft-versus-host disease after allogeneic peripheral stem cell transplantation. Bone Marrow Transplant 35(12): 1179-1186, 2005. PMID: 15852028. DOI: 10.1038/sj.bmt.1704972

13 Andersen J, Heilmann C, Jacobsen N, Nielsen C, Bendtzen K and Müller K: Differential effect of conditioning regimens on cytokine responses during allogeneic stem cell transplantation. Bone Marrow Transplant 37(7): 635-640, 2006. PMID: 16474409. DOI: 10.1038/sj.bmt.1705295

14 Liseth K, Sjo M, Paulsen K, Bruserud $\varnothing$ and Ersvaer E: Early preengraftment, functional, in vitro responsiveness of T lymphocytes in allotransplanted, acute leukemia patients: proliferation and release of a broad profile of cytokines, possibly predictive of graft-versus-host disease. Eur Cytokine Netw 21(1): 40-49, 2010. PMID: 20146989. DOI: 10.1684/ecn.2009.0181

15 Konuma T, Kohara C, Watanabe E, Mizukami M, Nagai E, Oiwa-Monna M, Tanoue S, Isobe M, Kato S, Tojo A and Takahashi S: Cytokine profiles of pre-engraftment syndrome after single-unit cord blood transplantation for adult patients. Biol Blood Marrow Transplant 23(11): 1932-1938, 2017. PMID: 28756243. DOI: 10.1016/j.bbmt.2017.07.020

16 Abu-Ghosh A, Goldman S, Slone V, van de Ven C, Suen Y, Murphy L, Sender L and Cairo M: Immunological reconstitution and correlation of circulating serum inflammatory mediators/cytokines 
with the incidence of acute graft-versus-host disease during the first 100 days following unrelated umbilical cord blood transplantation. Bone Marrow Transplant 24(5): 535-544, 1999. PMID: 10482939. DOI: 10.1038/sj.bmt.1701921

17 Harris DT, LoCascio J and Besencon FJ: Analysis of the alloreactive capacity of human umbilical cord blood: implications for graft-versus-host disease. Bone Marrow Transplant 14(4): 545-553, 1994. PMID: 7858529.

18 Ito C, Ribeiro RC, Behm FG, Raimondi SC, Pui CH and Campana D: Cyclosporin A induces apoptosis in childhood acute lymphoblastic leukemia cells. Blood 91(3): 1001-1007, 1998. PMID: 9446662.

19 Larssson R, Fridborg H, Csoka K, Bergh J and Nygren P: Cytotoxic action of cyclosporins on human tumor cell lines is not dependent on immunosuppressive activity. Anticancer Res 12(5): 1581-1585, 1992. PMID: 1444225.

20 Sezer O, Schweigert M, Naujokat C, Mai I, Mergenthaler HG and Possinger $\mathrm{K}$ : In vitro and in vivo correlation of cyclosporin A-induced apoptosis in acute lymphoblastic leukemia. Eur J Haematol 63(3): 207-209, 1999. PMID: 10485277. DOI: 10.1111/j.1600-0609.1999.tb01770.x

21 Medyouf H, Alcalde H, Berthier C, Guillemin MC, dos Santos NR, Janin A, Decaudin D, de Thé H and Ghysdael J: Targeting calcineurin activation as a therapeutic strategy for T-cell acute lymphoblastic leukemia. Nat Med 13(6): 736-741, 2007. PMID: 17515895. DOI: $10.1038 / \mathrm{nm} 1588$

22 Tosello V, Saccomani V, Yu J, Bordin F, Amadori A and Piovan E: Calcineurin complex isolated from T-cell acute lymphoblastic leukemia (T-ALL) cells identifies new signaling pathways including mTOR/AKT/S6K whose inhibition synergize with calcineurin inhibition to promote T-ALL cell death. Oncotarget 7(29): 4571545729, 2016. PMID: 27304189. DOI: 10.18632/oncotarget.9933

23 Shand JC, Jansson J, Hsu YC, Campbell A and Mullen CA: Differential gene expression in acute lymphoblastic leukemia cells surviving allogeneic transplant. Cancer Immunol Immunother 59(11): 1633-1644, 2010. PMID: 20602231. DOI: 10.1007/s00262-010-0889-y

24 Mihara K, Imai C, Coustan-Smith E, Dome JS, Dominici M, Vanin E and Campana D: Development and functional characterization of human bone marrow mesenchymal cells immortalized by enforced expression of telomerase. $\mathrm{Br} \mathrm{J}$ Haematol 120(5): 846-849, 2003. PMID: 12614220. DOI: 10.1046/j.1365-2141.2003.04217.x

25 Laboratory of Human Retrovirology and Immunoinformatics: David database for annotation, visualization and integrated discovery. Available at: https://david.ncifcrf.gov/ [Last accessed on May 20, 2021]

26 Djordjevic D, Kusumi K and Ho JW: XGSA: A statistical method for cross-species gene set analysis. Bioinformatics 32(17): i620-i628, 2016. PMID: 27587682. DOI: 10.1093/ bioinformatics/btw428

27 XGSA: Xgsa: A statistical method for cross-species gene set analysis. Available at: https://github.com/VCCRI/XGSA [Last accessed on May 20, 2021]

28 Gene Ontology: Gene ontology. Available at: http:// geneontology.org/ [Last accessed on May 20, 2021]

29 Ashburner M, Ball CA, Blake JA, Botstein D, Butler H, Cherry JM, Davis AP, Dolinski K, Dwight SS, Eppig JT, Harris MA, Hill DP, Issel-Tarver L, Kasarskis A, Lewis S, Matese JC, Richardson JE, Ringwald M, Rubin GM and Sherlock G: Gene ontology: tool for the unification of biology. The Gene Ontology Consortium. Nat Genet 25(1): 25-29, 2000. PMID: 10802651. DOI: $10.1038 / 75556$

30 Gene Ontology Consortium: The Gene Ontology resource: enriching a GOld mine. Nucleic Acids Res 49(D1): D325-D334, 2021. PMID: 33290552. DOI: 10.1093/nar/gkaa1113

31 Babraham Institute: Fastqc. Available at: https:// www.bioinformatics.babraham.ac.uk/projects/fastqc/ [Last accessed on May 20, 2021]

32 Dobin A, Davis CA, Schlesinger F, Drenkow J, Zaleski C, Jha S, Batut P, Chaisson $M$ and Gingeras TR: STAR: ultrafast universal RNA-seq aligner. Bioinformatics 29(1): 15-21, 2013. PMID: 23104886. DOI: 10.1093/bioinformatics/bts635

33 STAR: Star. Available at: https:/github.com/alexdobin/ STAR/releases [Last accessed on May 20, 2021]

34 Danecek P, Bonfield JK, Liddle J, Marshall J, Ohan V, Pollard MO, Whitwham A, Keane T, McCarthy SA, Davies RM and Li $\mathrm{H}$ : Twelve years of SAMtools and BCFtools. Gigascience 10(2): giab008, 2021. PMID: 33590861. DOI: 10.1093/gigascience/ giab008

35 Wellcome Trust Sanger Institute: Samtools. Available at: https://www.htslib.org/ [Last accessed on May 20, 2021]

36 Anders S, Pyl PT and Huber W: HTSeq - a Python framework to work with high-throughput sequencing data. Bioinformatics 31(2): 166-169, 2015. PMID: 25260700. DOI: 10.1093/ bioinformatics/btu638

37 Simon Anders: Htseq. Available at: https://github. $\mathrm{com} / \mathrm{htseq} / \mathrm{htseq}$ [Last accessed on May 20, 2021]

38 Love MI, Huber W and Anders S: Moderated estimation of fold change and dispersion for RNA-seq data with DESeq2. Genome Biol 15(12): 550, 2014. PMID: 25516281. DOI: 10.1186/ s13059-014-0550-8

39 Bioconductor: Deseq2. Available at: http://www.bio conductor.org/packages/release/bioc/html/DESeq2.html [Last accessed on May 20, 2021]

40 Subramanian A, Tamayo P, Mootha VK, Mukherjee S, Ebert BL, Gillette MA, Paulovich A, Pomeroy SL, Golub TR, Lander ES and Mesirov JP: Gene set enrichment analysis: a knowledgebased approach for interpreting genome-wide expression profiles. Proc Natl Acad Sci USA 102(43): 15545-15550, 2005. PMID: 16199517. DOI: 10.1073/pnas.0506580102

41 Mootha VK, Lindgren CM, Eriksson KF, Subramanian A, Sihag S, Lehar J, Puigserver P, Carlsson E, Ridderstråle M, Laurila E, Houstis N, Daly MJ, Patterson N, Mesirov JP, Golub TR, Tamayo P, Spiegelman B, Lander ES, Hirschhorn JN, Altshuler $\mathrm{D}$ and Groop LC: PGC-1alpha-responsive genes involved in oxidative phosphorylation are coordinately downregulated in human diabetes. Nat Genet 34(3): 267-273, 2003. PMID: 12808457. DOI: $10.1038 / \mathrm{ng} 1180$

42 Abbas AK, Lichtman AH and Pillai S: Immunity to microbes. In: Cellular and molecular immunology. 10 ed. Elsevier, pp. 365388, 2022.

43 de Bruin AM, Voermans C and Nolte MA: Impact of interferon$\gamma$ on hematopoiesis. Blood 124(16): 2479-2486, 2014. PMID: 25185711. DOI: $10.1182 /$ blood-2014-04-568451

44 Fidanza M, Seif AE, Jo S, Kariminia A, Rolf N, Sly LM, Grupp SA and Reid GSD: IFN- $\gamma$ directly inhibits murine B-cell precursor leukemia-initiating cell proliferation early in life. Eur J Immunol 47(5): 892-899, 2017. PMID: 28295300. DOI: 10.1002/eji.201646806 
45 Traxel S, Schadt L, Eyer T, Mordasini V, Gysin C, Munthe LA, Niggli F, Nadal D and Bürgler S: Bone marrow T helper cells with a Th1 phenotype induce activation and proliferation of leukemic cells in precursor B acute lymphoblastic leukemia patients. Oncogene 38(13): 2420-2431, 2019. PMID: 30532071 DOI: $10.1038 / \mathrm{s} 41388-018-0594-4$

46 Yeshurun M, Weisdorf D, Rowe JM, Tallman MS, Zhang MJ, Wang HL, Saber W, de Lima M, Sandmaier BM, Uy G, Kamble RT, Cairo MS, Cooper BW, Cahn JY, Ganguly S, Camitta B, Verdonck LF, Dandoy C, Diaz MA, Savani BN, George B, Liesveld J, McGuirk J, Byrne M, Grunwald MR, Drobyski WR, Pulsipher MA, Abdel-Azim H, Prestidge T, Wieduwilt MJ, Martino R, Norkin M, Beitinjaneh A, Seo S, Nishihori T, Wirk B, Frangoul H, Bashey A, Mori S, Marks DI and Bachanova V: The impact of the graft-versus-leukemia effect on survival in acute lymphoblastic leukemia. Blood Adv 3(4): 670-680, 2019. PMID: 30808685. DOI: 10.1182/bloodadvances.2018027003

47 Ringdén O, Karlsson H, Olsson R, Omazic B and Uhlin M: The allogeneic graft-versus-cancer effect. Br J Haematol 147(5): 614633, 2009. PMID: 19735262. DOI: 10.1111/j.1365-2141.2009. 07886.x
48 Zhang J, Chen HM, Ma G, Zhou Z, Raulet D, Rivera AL, Chen SH and Pan PY: The mechanistic study behind suppression of GVHD while retaining GVL activities by myeloid-derived suppressor cells. Leukemia 33(8): 2078-2089, 2019. PMID: 30737483. DOI: 10.1038/s41375-019-0394-Z

49 Wang L, Du F, Wang H and Xie C: Cooperation of CD4+ T cells and $\mathrm{CD}^{+} \mathrm{T}$ cells and release of $\mathrm{IFN}-\gamma$ are critical for antileukemia responses of recipient mice treated by microtransplantation. Exp Ther Med 15(2): 1532-1537, 2018. PMID: 29399128. DOI: 10.3892/etm.2017.5541

50 Liu Y, Wang L, Kikuiri T, Akiyama K, Chen C, Xu X, Yang R, Chen W, Wang S and Shi S: Mesenchymal stem cell-based tissue regeneration is governed by recipient T lymphocytes via IFN- $\gamma$ and TNF- $\alpha$. Nat Med 17(12): 1594-1601, 2011. PMID: 22101767. DOI: $10.1038 / \mathrm{nm} .2542$

Received March 10, 2021

Revised May 18, 2021

Accepted May 20, 2021 